\title{
Adipotropic effects of heavy metals and their potential role in obesity
}

\author{
Alexey A. Tinkov ${ }^{1,2}$ Michael Aschner (iD ${ }^{1,3^{*}} \quad$ Tao Ke $^{3} \quad$ Beatriz Ferrer $^{3} \quad$ Ji-Chang Zhou $^{4} \quad$ Jung-Su Chang $^{5}$ \\ Abel Santamaría $^{6}$ Jane C.-J. Chao ${ }^{5,7}$ Jan Aaseth ${ }^{1,8} \quad$ Anatoly V. Skalny ${ }^{1}$ \\ ${ }^{1}$ IM Sechenov First Moscow State Medical University (Sechenov University), Moscow, Russia \\ ${ }^{2}$ Yaroslavl State University, Yaroslavl, Russia \\ ${ }^{3}$ Department of Molecular Pharmacology, Albert Einstein College of Medicine, Bronx, NY, USA \\ ${ }^{4}$ School of Public Health (Shenzhen), Sun Yat-sen University, Shenzhen, China \\ ${ }^{5}$ Taipei Medical University, Taipei, Taiwan \\ ${ }^{6}$ Laboratorio de Aminoácidos Excitadores, Instituto Nacional de Neurología y Neurocirugía, S.S.A., Mexico City, Mexico \\ ${ }^{7}$ Nutrition Research Center, Taipei Medical University Hospital, Taipei, Taiwan \\ ${ }^{8}$ Research Department, Innlandet Hospital Trust, Brumunddal, Norway
}

\begin{abstract}
Epidemiological studies demonstrated an association between heavy metal exposure and the incidence of obesity and metabolic syndrome. However, the particular effects of metal toxicity on adipose tissue functioning are unclear. Therefore, recent findings of direct influence of heavy metals (mercury, cadmium, and lead) and metalloid (arsenic) on adipose tissue physiology are discussed while considering existing gaps and contradictions. Here, we provide a literature review addressing adipose tissue as a potential target of heavy metal toxicity. Experimental in vivo studies demonstrated a significant influence of mercury, cadmium, lead, and arsenic exposure on body adiposity. In turn, in vitro experiments revealed both up- and downregulation of adipogenesis associated with aberrant expression of key adipogenic pathways, namely CCAAT/enhancer-binding protein (C/ EBP) and peroxisome proliferator-activated receptor gamma (PPAR $\gamma$ ). Comparison of the existing studies on the basis of dose and route of exposure demonstrated that the effects of heavy metal exposure on adipose tissue may be dose-dependent, varying from increased adipogenesis at low-dose exposure to inhibition of adipose tissue differentiation at higher doses. However, direct dose-response data are available in a single study only for arsenic. Nonetheless, both types of these effects, irrespective of their directionality, contribute significantly to metabolic disturbances due to dysregulated adipogenesis. Particularly, inhibition of adipocyte differentiation is known to reduce lipid-storage capacity of adipose tissue, leading to ectopic lipid accumulation. In contrast, metal-associated stimulation of adipogenesis may result in increased adipose tissue accumulation and obesity. However, further studies are required to reveal the particular dose- and species-dependent effects of heavy metal exposure on adipogenesis and adipose tissue functioning.
\end{abstract}

\section{Keywords}

mercury, cadmium, lead, adipogenesis, adipocyte 


\section{Peer Review}

The peer reviewers who approve this article are:

1. Jen-Chywan Wang, Superfund Research Program, Department of Nutritional Sciences \& Toxicology, University of California, Berkeley, California, USA

Competing interests: No competing interests were disclosed.

2. Marion Ehrich, Department of Biomedical Sciences and Pathobiology, Virginia Tech, Blacksburg, VA, USA Competing interests: No competing interests were disclosed.

*Corresponding author: Michael Aschner (michael.aschner@einsteinmed.org)

Competing interests: The authors declare that they have no competing interests.

Grant information: The current investigation is supported by the Russian Foundation for Basic Research within project 20-515-S52003. MA was supported in part by National Institutes of Health grants NIEHS R01 10563 and R01ES07331.

Copyright: (C) 2021 Aschner M et al. This is an open access article distributed under the terms of the Creative Commons Attribution License, which permits unrestricted use, distribution, and reproduction in any medium, provided the original work is properly cited.

How to cite this article: Tinkov AA, Aschner M, Ke T, Ferrer B, Zhou JC, Chang JS, Santamaría A, Chao JCJ, Aaseth J and Skalny AV. Adipotropic effects of heavy metals and their potential role in obesity. Faculty Reviews 2021 10:(32) https://doi.org/10.12703/r/10-32

Published: 26 Mar 2021, Faculty Reviews 10:(32) https://doi.org/10.12703/r/10-32 


\section{Introduction}

Adipose tissue is a metabolically active tissue that evolutionarily developed as a specialized lipid depot also capable of secreting a wide range of signaling molecules (adipokines) ${ }^{1}$. Perturbations in adipose tissue physiology are known to be implicated in a wide range of metabolic disturbances, and obesity is the most widespread ${ }^{2}$. Findings in the last decades demonstrated that exposure to environmental pollutants may play a significant role in the development of obesity because of their role as endocrine disruptors, raising the concept of "obesogens"3. Known chemical obesogens include phenols, polycyclic aromatic hydrocarbons, amides, metallic compounds, esters, halogenated compounds, air pollutants, and flavoring agents, to name a few ${ }^{4}$.

Specifically, both epidemiological and experimental studies demonstrated an association between persistent organic pollutant exposure and pathogenesis of obesity and this was due mainly to interference with adipogenesis through modulation of peroxisome proliferator-activated receptor gamma (PPAR $\gamma$ ) and CCAAT/enhancer-binding protein (C/EBP) expression. Certain obesogens-organotin compounds, in particular-are considered agonists of nuclear receptors (PPAR $\gamma$ and RXR). Transgenerational effects of obesogens may also be mediated through epigenetic mechanisms, including altered DNA and histone methylation, as well as impaired chromatin structure ${ }^{4}$.

Recent findings demonstrated the association between heavy metal exposure and prevalence of obesity. Exposure to markers of mercury ${ }^{5}$, cadmium ${ }^{6}$, lead $^{7}$, and arsenic $^{8}$ as well as metal mixture $^{9}$ were found to be correlated with anthropometric and metabolic parameters in obesity and metabolic syndrome. However, the only metal considered a classic obesogen is tin $(\mathrm{Sn})$, particularly its organic compounds, organotins ${ }^{10}$, which, being both PPAR $\gamma$ and RXR agonists, were shown to interfere with adipogenesis ${ }^{11}$. Data on the impact of other metals on adipogenesis and adipocyte functions are extremely insufficient. Specifically, a crude PubMed-Medline search using the terms "adipocyte" and "cadmium" or "mercury" revealed 21 and 13 papers, compared with 52, (48) 193, and 77 for "organotin", "(polychlorinated) biphenyl", and "dioxin", respectively, indicating a scant number of studies on the adipocyte-targeted effects of heavy metals. Therefore, we aimed to discuss recent findings on the direct influence of heavy metals $(\mathrm{Hg}, \mathrm{Cd}$, and $\mathrm{Pb})$ and metalloid (As) on adipose tissue physiology in view of the existing gaps and contradictions.

\section{A brief introduction to the role of adipose tissue in the regulation of body adiposity}

The cardinal morphological feature of obesity is increased white adipose tissue (WAT) mass (adiposity) that results from the imbalance between energy intake and energy expenditure. At positive caloric balance, excessive energy is stored as lipids in adipocyte lipid droplets as a result of lipogenesis, whereas increased energy expenditure activates mobilization of the stored lipids through lipolysis, which is regulated by neuroendocrine signals ${ }^{12}$. In parallel to the changes in adipocyte size, which are dependent on the balance between lipogenic and lipolytic enzymes, adipose tissue remodeling is also associated with modulation of adipogenesis ${ }^{13}$. Adipogenesis is the process of proliferation and subsequent maturation of adipocytes from adipocyte progenitors regulated by $\mathrm{C} / \mathrm{EBPs}$ and PPAR $\gamma$ to meet the increasing lipid-storing requirements. In turn, adipogenesis dysregulation was shown to be associated with altered metabolic profile in obesity ${ }^{14}$. In addition, owing to the role of adipose tissue as an endocrine organ, adipocyte dysfunction results in impaired adipokine secretion ${ }^{15}$. Leptin, the main endocrine product of adipose tissue, is known to play a significant role in the central control of energy balance by influencing hypothalamic centers of appetite and satiety, also underlining the role of adipose tissue in the regulation of energy intake. Therefore, altered leptin signaling is known to be associated with impaired feeding behavior and obesity ${ }^{16}$. It is also notable that under certain signals WAT may modulate energy expenditure through modulation of beige adipogenesis and white-to-beige adipocyte transformation and subsequent beige thermogenesis. In turn, beige-to-white adipocyte transformation may further aggravate obesity ${ }^{17}$. Therefore, the role of adipose tissue is mediated not only by its role as lipid reservoir but also through modulation of adipogenesis, adipokine secretion, involvement in the central regulation of appetite and satiety as well as the capability to regulate thermogenesis via beige ("brite") adipocyte formation ${ }^{18}$.

\section{Adipotropic effects of heavy metals Mercury $(\mathrm{Hg})$}

High total blood $\mathrm{Hg}$ levels were found to be associated with significantly increased visceral adipose tissue mass in Korean adults $^{19}$. Experimental studies also demonstrated the impact of $\mathrm{Hg}$ exposure on adipose tissue accumulation. Specifically, periconceptional maternal exposure to methylmercury ( $\mathrm{MeHg}$ ) and cadmium chloride $\left(\mathrm{CdCl}_{2}\right)$ (both $2 \mathrm{mg} / \mathrm{kg}$ ) resulted in increased adipose tissue mass and body weight in offspring with transgenerational effect that persisted to the $\mathrm{F} 4$ generation $^{20}$.

Rizzetti et al. (2019) demonstrated that mercury chloride $\left(\mathrm{HgCl}_{2}\right)$, when injected intramuscularly $(4.6 \mu \mathrm{g} / \mathrm{kg}$ as the first dose with subsequent $0.07 \mu \mathrm{g} / \mathrm{kg}$ per day exposure for 60 days) to male Wistar rats, may be considered a "powerful environmental WAT disruptor" that is capable of reducing adipocyte size ${ }^{21}$. The latter was shown to be accompanied by increased adiponectin, leptin, PPAR $\alpha$, and PPAR $\gamma$ mRNA expression, indicative of impaired adipogenesis and adipokine secretion. The revealed increase in adipose tissue GRP78, CHOP, and CD11 mRNA expression indicated the potential role of endoplasmic reticulum stress and pro-inflammatory signaling in $\mathrm{Hg}$-induced alteration of adipose tissue physiology ${ }^{21}$. These findings only partially corroborate the pioneering observation by Kawakami et al. $(2012)^{22}$, who also demonstrated $\mathrm{Hg}$-induced decrease in adipose tissue mass and adipocyte size when high-fat diet 
(HFD)-fed male Slc:ICR mice were subcutaneously injected with $1.0 \mathrm{mg} / \mathrm{kg}$ body weight $\mathrm{HgCl}_{2}$. However, inorganic mercury exposure in HFD-fed animals significantly reduced WAT-specific leptin, PPAR $\alpha$, and PPAR $\gamma$ mRNA expression that may be at least partially mediated by $\mathrm{Hg}$-induced AMPK upregulation ${ }^{22}$. Certain inconsistencies between the adipotropic effects of $\mathrm{Hg}$ reported in these two studies may be explained by the difference in the dose of metal exposure; higher dose ${ }^{22}$ results in adipogenic response inhibition due to the potential toxic (including pro-oxidant) effects. In addition to the studies in mice demonstrating a significant impact of $\mathrm{Hg}$ exposure on PPAR $\gamma$, our recent findings from a Caenorhabditis elegans model revealed a significant impact of 10 to $20 \mu \mathrm{M} \mathrm{MeHg}$ on lipid metabolism regulatory genes, including pro-adipogenic worm orthologs to human SREBP and $\mathrm{C} / \mathrm{EBPs}^{23}$, due to $\mathrm{MeHg}$ being another regulator of adipogenesis. In contrast to the previously mentioned studies, one study demonstrated that in C57BL/6J mice orally exposed to 0.5 or $5 \mathrm{ppm} \mathrm{MeHg}$ (concentrations that failed to induce adipogenic gene expression in visceral adipose tissue), a reduction of adipose tissue cumulation was associated with $\mathrm{MeHg}$-induced increase in hypothalamic pro-opiomelanocortin (POMC) expression ${ }^{24}$. Given the role of POMC as an anorexigenic peptide that reduces food intake ${ }^{25}$, the obtained data are indicative of the role of central effects of $\mathrm{Hg}$ in the modulation of body adiposity ${ }^{24}$.

The role of $\mathrm{Hg}$ as a potential factor affecting adipogenesis was also demonstrated in in vitro studies. The most recent study demonstrated that $\mathrm{MeHg}$ exposure in vitro $(0,0.3,1.7$, or $3.8 \mathrm{mM}$ ) for 6 days increased lipid accumulation in 3T3-L1 preadipocytes isolated from perivisceral adipose tissue. Although these changes were accompanied by an increase in fatty acid synthase and perilipin expression, certain other adipogenic markers, namely fatty acid transport protein 1, glycerol-3-phosphate dehydrogenase, and $\mathrm{C} / \mathrm{EBP} \delta$, were downregulated $^{26}$. It is also notable that $\mathrm{Hg}$ is capable of regulating adipogenesis-related genes, including $C / E B P \beta, D D I T 3$ (both upregulation), LPIN1, and SREBF1 (both downregulation), in BEAS-2B cells when administered together with 2,3,7,8-tetrachlorodibenzo-p-dioxin (TCDD) ${ }^{27}$.

The observed effects of $\mathrm{Hg}$ on adipogenesis also corroborated in vitro data on its impact on adipokine secretion. Specifically, treatment of 3T3-L1 adipocytes to $200 \mathrm{ng} / \mathrm{mL} \mathrm{MeHg}$ resulted in the formation of a lower number of adipocytes and clumped lipid droplets as well as activation of apoptosis through induction of oxidative stress as evaluated by increased culture 4-hydroxynonenal (4-HNE) levels. These changes were accompanied by aberrant adipokine expression patterns characterized predominantly by elevated adiponectin and resistin production $^{28}$. In addition, $\mathrm{MeHg}$ exposure (100-200 ng/mL) resulted in a significant increase in vascular endothelial growth factor (VEGF) production, which is known to play a certain role in the pathogenesis of metabolic syndrome ${ }^{29}$, in mature 3T3-L1 adipocytes ${ }^{30}$.
Lead $(\mathrm{Pb})$

$\mathrm{Pb}$ effectively accumulates in human adipose tissue ${ }^{31}$, although direct effects of $\mathrm{Pb}$ exposure on adipocyte physiology have yet to be discerned. Lifetime $\mathrm{Pb}$ exposure (200-500 ppm) in $\mathrm{C} 57 \mathrm{Bl} / 6$ mice resulted in a significant increase in bone marrow adiposity characterized by increased adipocyte size and number through upregulation of PPAR $\gamma$ gene expression ${ }^{32}$, indicative of $\mathrm{Pb}$-induced adipogenesis. The results of in vitro studies have also demonstrated a significant effect of $\mathrm{Pb}$ on adipogenesis through modulation of key regulators (PPAR $\gamma$ and C/EBP $\beta$ ). Particularly, a study in 3T3-L1 fibroblasts demonstrated that $\mathrm{Pb}$ exposure $(0-10 \mu \mathrm{M})$ increased cytosolic lipid accumulation and perilipin expression occurring during adipogenesis. These effects were mediated by upregulation of $\mathrm{C} / \mathrm{EBP} \beta$ and ERK expression with subsequent activation of PPAR $\gamma^{33}$. These findings corroborate earlier observations on the interactive effects of $\mathrm{Pb}$ exposure $(2 \mu \mathrm{M})$ and high-fat medium on the expression of proadipogenic $\operatorname{PPAR} \gamma$ and adipogenic marker fatty acid-binding protein 4 (FABP4) in MC3T3-E1 cells $^{34}$. However, higher concentrations $(>10 \mu \mathrm{M})$ of $\mathrm{Pb}$ were shown to inhibit proliferation of 3T3-L1 fibroblasts ${ }^{35}$ that may be associated with toxic effects of increasing metal concentrations.

It is also notable that $\mathrm{Pb}$ exposure may affect central adipokine signaling through downregulating adiponectin receptor $1 \mathrm{~b}$ and especially leptin receptor gene expression in zebrafish brain $^{36}$. Given the role of altered leptin receptor expression in leptin resistance and obesity ${ }^{37}$, these findings may be indicative of the central role of $\mathrm{Pb}$ in alterations of energy homeostasis and excessive adiposity.

\section{Arsenic (As)}

As was considered a potential obesogen affecting normal adipose tissue physiology, although direct data on the impact of As species on adipogenesis and adipocyte functions are inconsistent ${ }^{38}$. Experimental in vivo studies demonstrated that As exposure is capable of affecting WAT mass, although the observed effects of As on adipogenesis seem to be dosedependent. Specifically, exposure to As-containing drinking water $\left(300 \mu \mathrm{g} / \mathrm{L}\right.$ sodium arsenite $\left.\left[\mathrm{NaAsO}_{2}\right]\right)$ for 9 weeks in male C57BL/6J mice resulted in a significant increase in WAT mass, accompanied by impaired mitochondrial biogenesis and thermogenesis due to modulation of PPAR $\alpha$ and PPAR $\gamma$-specific genes, including Slc27a2, Fabp3, Ucp1, Acsl5, Scd2, and Cpt1 $\beta^{39}$. However, exposure to a higher dose $(50 \mathrm{mg} / \mathrm{L}$ for 16 weeks) significantly reduced adipose tissue mass in HFD-fed male C57BL/6J mice without alteration of energy expenditure as assessed by indirect calorimetry ${ }^{40}$. The authors propose that the observed "antiobesogenic" effect of As could be attributed to its insulin-sensitizing activity ${ }^{40}$. Of interest, an inverse association between As dose and adipogenic response was reported by Shearer et al. $(2017)^{41}$. Particularly, oral exposure to 300 $\mathrm{ppb}$ inorganic As in male C57BL/6J mice resulted in a significant decrease in the expression of adipocyte-specific genes in isolated adipose-derived mesenchymal stem/stromal cells (ASCs), 
whereas ASCs obtained from mice exposed to a higher dose $(1000 \mathrm{ppb})$ were characterized by a significant increase in adiponectin, leptin, and FABP4 expression, indicative of a biphasic response of adipogenesis to inorganic As exposure ${ }^{41}$.

High-dose As exposure was also shown to alter the production of adiponectin. Drinking $\mathrm{NaAsO}_{2}$-containing water (5 and $50 \mathrm{ppm}$ in drinking water) for 18 weeks resulted in a significant decrease in serum adiponectin levels in male C57BL/6 mice $^{42}$. However, the impact of As on adiponectin production seems to be diet-dependent. Particularly, As exposure in male mice fed a low- and high-fat diet resulted in a significant decrease and increase of circulating adiponectin levels, respectively ${ }^{43}$. Reduced levels of adiponectin in response to As toxicity may also indirectly indicate inhibitory effects of the metalloid on adipogenesis and production of adipocyte-specific proteins, although this relationship may be mediated by factors such as insulin resistance, inflammation, atherogenic dyslipidemia, and total body adiposity ${ }^{44}$.

The existing in vitro studies further unraveled the mechanisms underlying the modulatory effect of As on adipogenesis. Generally, previously discussed in vivo studies corroborate earlier data on the inhibitory effect of As $(0.2-4 \mu \mathrm{M})$ on adipogenic differentiation of mesenchymal stem cells through downregulation of PPAR $\gamma$ and C/EBP expression ${ }^{45}$. The results of a recent study performed in stromal vascular fraction cells isolated from WATs of Nrf1(f)-knockout mice allow investigators to propose that As-induced inhibition of PPAR $\gamma$ signaling and adipogenesis may be NRF1-dependent ${ }^{46}$. Inhibition of PPAR $\gamma$ signaling was shown to occur because of As $(5-10 \mu \mathrm{M})$-induced endoplasmic reticulum stress in 3T3-L1 preadipocytes with subsequent induction of $\mathrm{C} / \mathrm{EBP}$ homologous protein (CHOP10) that is known to reduce C/EBP $\beta$ DNAbinding activity ${ }^{47}$. Modulation of SIRT3-FOXO3a, endothelin-1, Ras-MAP-AP-1, and PI3K-Akt pathways by As exposure may also significantly contribute to disturbed adipocyte functioning ${ }^{48}$. As exposure $(0$ or $100 \mu \mathrm{g} / \mathrm{L}$ in drinking water or $1 \mu \mathrm{M}$ in culture medium) was also shown to inhibit adipogenesis by increasing miR-29b in human mesenchymal stem cells and murine adipose tissue and sustained cyclin D expression, preventing cell cycle exit and providing a shift from differentiation to proliferation ${ }^{49}$.

Brown adipose tissue (BAT) was also shown to be the potential target of As toxicity mediating the effects of the metalloid on body adiposity. Specifically, oral administration of $\mathrm{NaAsO}_{2}$ $(5-10 \mathrm{mg} / \mathrm{kg})$ to male C57BL/6J mice was accompanied by a more pronounced As accumulation in BAT as compared with WAT and also resulted in inhibition of brown adipocyte differentiation and decreased expression of PPAR $\gamma$ and other brown adipocyte-specific markers (UCP1 and PGC1). Moreover, As-induced inhibition of autophagy was proposed to play a role in BAT dysfunction ${ }^{50}$. Correspondingly, prolonged exposure of adult $\mathrm{C} 57 \mathrm{BL} / 6 \mathrm{~J}$ female mice to inorganic As
(5-20 ppm in drinking water for 17 weeks) was shown to impair energy homeostasis, resulting in metabolic disturbances attributed to BAT whitening and impaired thermogenesis ${ }^{51}$. These findings corroborate data on As-induced alteration of mitochondrial biogenesis and beige adipocyte formation, indicative of the significant role of reduced thermogenesis in the observed increase in adiposity ${ }^{40}$.

\section{Cadmium (Cd)}

Although the role of $\mathrm{Cd}$ exposure in the development of diabetes mellitus type 2 was demonstrated in epidemiological and laboratory studies, the mechanisms of particular involvement of $\mathrm{Cd}$ in obesity pathogenesis are unclear ${ }^{6}$. Owing to high abundance in the human body, adipose tissue was considered a significant $\mathrm{Cd}$ depot in spite of a rather low $\mathrm{Cd}$ level $(42 \mu \mathrm{g} / \mathrm{kg})^{52}$. Correspondingly, Cd levels in adipose tissue were found to be directly associated with smoking ${ }^{53}$, which was the most significant source of non-occupational metal exposure. These findings indicate that adipose tissue may be considered a potential target for $\mathrm{Cd}$ toxicity. However, data on the particular effects of $\mathrm{Cd}$ in adipose tissue or adipocyte cultures are inconsistent ${ }^{6}$.

Cd levels in prenatal blood were found to be significantly associated with the risk of pediatric obesity in children (4 to 5 years old) living in North Carolina and this is in agreement with the effects of prenatal $\mathrm{Cd}$ exposure on juvenile lipid accumulation in zebrafish ${ }^{54}$. Early-life low-dose $\mathrm{Cd}$ exposure (100 $\mathrm{nM} \mathrm{CdCl}$, with drinking water) was shown to increase body mass, adiposity, and elevated leptin levels in male C57BL/6J mice ${ }^{55}$. It is also notable that periconceptional exposure to $\mathrm{Cd}$ and $\mathrm{Hg}$ ( $2 \mathrm{mg} / \mathrm{kg}$ each) in $\mathrm{CD} 1$ mice caused transgenerational metabolic effects characterized by abdominal obesity and glucose intolerance up to the F4 generation, although the particular impact of combined metal exposure on adipogenesis was not specified $^{20}$. The observed effects of $\mathrm{Cd}$ on body adiposity may be mediated by its impact on adipogenesis as demonstrated in vitro. Particularly, chronic exposure to 0.5 to $2 \mu \mathrm{mol} / \mathrm{L} \mathrm{CdCl}_{2}$ was shown to increase the abundance of bone marrow adipocytes through upregulation of mesenchymal stem cell adipogenic differentiation with concomitant upregulation of PPAR $\gamma$ expression ${ }^{56}$.

However, certain in vivo and in vitro studies reported opposite effects of $\mathrm{Cd}$ exposure on adipose tissue cellularity and function and were also supported by epidemiological data. Particularly, a study originating from Mexico City demonstrated an inverse association between maternal urinary $\mathrm{Cd}$ levels and abdominal and peripheric adiposity ${ }^{57}$. An experimental in vivo study demonstrated that administration of $100 \mathrm{ppm} \mathrm{CdCl}_{2}$ in drinking water to ICR mice for 8 weeks resulted in a significant decrease in adipocyte size but that $\mathrm{Cd}$ chelation using dimercaptosuccinic acid (DMSA) ameliorated this effect ${ }^{58}$. This effect may be at least partially mediated by the earlier demonstrated Cd-induced $(3 \mu \mathrm{M})$ inhibition of adipogenesis 
and a dose-dependent decrease in C/EBP $\alpha$ and PPAR $\gamma$ protein expression in $3 \mathrm{~T} 3-\mathrm{L} 1$ preadipocytes $^{59}$.

The existing experimental studies revealed significant contradictions in the effects of $\mathrm{Cd}$ on adiposity and adipogenesis in particular. Hypothetically, "low"-dose exposure in vivo $\left(100 \mathrm{nM} \mathrm{CdCl}_{2}\right.$ with drinking water, $\mathrm{C} 57 \mathrm{BL} / 6 \mathrm{~J}$ mice $\left.^{55}\right)$ and in vitro $\left(0.5-2 \mu \mathrm{mol} / \mathrm{L} \mathrm{CdCl}_{2}\right.$, bone marrow adipocytes $\left.{ }^{56}\right)$ may promote body adiposity through upregulation of adipogenesis, whereas "high" doses studied in ICR mice (100 ppm $\mathrm{CdCl}_{2}$ in drinking water $^{58}$ ) and 3 T3-L1 preadipocytes $\left(3 \mu \mathrm{M}^{59}\right)$ may reduce adipose tissue levels at least partially through inhibition of adipogenesis.

\section{Conclusion and perspectives}

Generally, the existing in vivo and in vitro studies demonstrate that heavy metal(loid)s affect adipose tissue mass and function through modulation of adipogenesis (via $\mathrm{C} / \mathrm{EBP} \alpha$ and $\mathrm{PPAR} \gamma$ ), indicating the "adipotropic" effects of heavy metals. Despite some existing contradictions, the experimental data provide insight into dose-dependent effects of heavy metals on adipogenesis. It is proposed that the effects of heavy metal exposure on adipose tissue is biphasic (Figure 1), varying from increased adipogenesis at low-dose exposure to inhibition of adipose tissue differentiation at higher doses, as demonstrated for $\mathrm{Hg}^{21,22}, \mathrm{Cd}^{55,56,58,59}$, and $\mathrm{As}^{41}$. However, direct dose-response analysis was performed only for the latter ${ }^{41}$. Similar patterns of biological action were shown to underlie the hermetic effect of chemical substances, including heavy metals and metal nanoparticles ${ }^{60}$.

Both stimulation and inhibition of adipogenesis in response to heavy metal exposure might contribute significantly to metabolic disturbances. Particularly, inhibition of adipocyte differentiation is known to reduce lipid-storage capacity of adipose tissue, leading to ectopic lipid accumulation ${ }^{61}$. This assumption is indirectly confirmed by the observed association between heavy metal exposure and non-alcoholic fatty liver disease ${ }^{62-64}$. On the other hand, metal-associated stimulation of adipogenesis may result in increased adipose tissue accumulation and obesity. At the same time, in view of pro-inflammatory and pro-oxidant ${ }^{65,66}$ effects of heavy metals as well as their contribution to insulin resistance ${ }^{67}$, expanded adipose tissue seems to be dysfunctional, also contributing to aggravated metabolic risk.

Further studies are required to reveal the particular dose- and species-dependent effects of heavy metal exposure on adipogenesis and adipose tissue functioning. Moreover, it is unclear whether other toxic metals, including aluminum, nickel, and beryllium, may also target adipose tissue. These findings could help to unravel the particular role of heavy metal exposure in obesity and metabolic syndrome and the subsequent development of protective strategies.

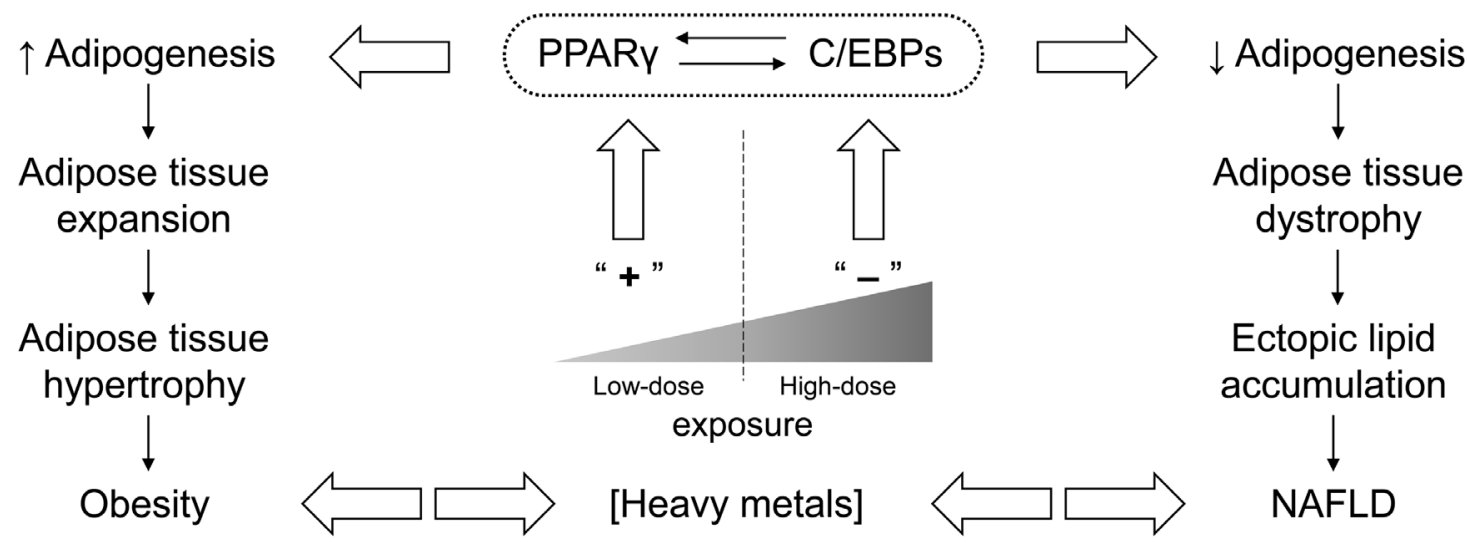

Figure 1. A schematic representation of biphasic adipogenic response to heavy metal exposure. Briefly, low-dose exposure (left) may upregulate key adipogenic factors C/EBPs and PPARy, thus promoting excessive adipogenesis and contributing to obesity and diabetes mellitus. In turn, "high-dose" metal exposure (right) may inhibit adipogenesis through downregulation of C/EBPs and PPAR $\gamma$ that may be associated with toxic effects of the metals because of pro-inflammatory and pro-oxidant activity. Under positive caloric balance, reduced adipogenic capacity results in increased ectopic lipid accumulation and lipotoxicity, including that in non-alcoholic fatty liver disease (NAFLD). However, in vivo and in vitro dose-response studies are required to clarify the association between toxic metal exposure and adipogenesis. C/EBP, CCAAT/enhancer-binding protein; PPAR $\gamma$, peroxisome proliferator-activated receptor gamma. 
1. Zwick RK, Guerrero-Juarez CF, Horsley V, et al:: Anatomical, Physiological, and Functional Diversity of Adipose Tissue. Cell Metab. 2018; 27(1): 68-83. PubMed Abstract | Publisher Full Text | Free Full Text

2. Trim W, Thompson D, Turner JE: Adipose Tissue Dysfunction. In Encyclopedia of Behavioral Medicine. Living edition. Edited by Gellman M. Springer. 2018; 1-5. Publisher Full Text

3. Trasande L, Blumberg B: Endocrine disruptors as obesogens. In Pediatric Obesity. Contemporary Endocrinology. Edited by Freemark MS. Humana Press, Cham. 2018; 243-253. Publisher Full Text

4. Egusquiza RJ, Blumberg B: Environmental Obesogens and Their Impact on Susceptibility to Obesity: New Mechanisms and Chemicals. Endocrinology. 2020; 161(3): bqaa024

PubMed Abstract | Publisher Full Text | Free Full Text

5. Lee K: Blood mercury concentration in relation to metabolic and weigh phenotypes using the KNHANES 2011-2013 data. Int Arch Occup Environ Health. 2018; 91(12): 185-93.

PubMed Abstract | Publisher Full Text

6. Tinkov AA, Filippini T, Ajsuvakova OP, et al:: The role of cadmium in obesity and diabetes. Sci Total Environ. 2017; 601-602: 741-55.

PubMed Abstract | Publisher Full Text

7. Wang G, DiBari J, Bind E, et al:: Association Between Maternal Exposure to Lead, Maternal Folate Status, and Intergenerational Risk of Childhood Overweight and Obesity. JAMA Netw Open. 2019; 2: e1912343. PubMed Abstract | Publisher Full Text | Free Full Text

8. Stahr S, Su J: Positive association between salivary arsenic concentration and obesity in a pilot study of women living in rural communities in the United States. Environmental Epidemiology. 2019; 3: 381. Publisher Full Text

9. Wang X, Mukherjee B, Park SK: Associations of cumulative exposure to heavy metal mixtures with obesity and its comorbidities among U.S. adults in NHANES 2003-2014. Environ Int. 2018; 121(Pt 1): 683-94. PubMed Abstract | Publisher Full Text | Free Full Text

10. Chamorro-Garcia R, Blumberg B: Current Research Approaches and Challenges in the Obesogen Field. Front Endocrinol (Lausanne). 2019; 10: 167. PubMed Abstract | Publisher Full Text | Free Full Text

11. Tinkov AA, Ajsuvakova OP, Skalnaya MG, et al.: Organotins in obesity and associated metabolic disturbances. J Inorg Biochem. 2019; 191: 49-59. PubMed Abstract | Publisher Full Text

12. Braun $\mathrm{K}$, Oeckl J, Westermeier $\mathrm{J}$, et al:: Non-adrenergic control of lipolysis and thermogenesis in adipose tissues. J Exp Biol. 2018; 221(Pt Suppl 1): jeb165381. PubMed Abstract | Publisher Full Text

13. Choe SS, Huh JY, Hwang IJ, et al.: Adipose Tissue Remodeling: Its Role in Energy Metabolism and Metabolic Disorders. Front Endocrinol (Lausanne). 2016; 7: 30

PubMed Abstract | Publisher Full Text | Free Full Text

14. Vishvanath L, Gupta RK: Contribution of adipogenesis to healthy adipose tissue expansion in obesity. J Clin Invest. 2019; 129(10): 4022-4031. PubMed Abstract | Publisher Full Text | Free Full Text

15. Longo M, Zatterale F, Naderi J, et al:: Adipose Tissue Dysfunction as Determinant of Obesity-Associated Metabolic Complications. Int J Mol Sci. 2019; 20(9): 2358.

PubMed Abstract | Publisher Full Text | Free Full Text

16. Pandit R, Beerens S, Adan RAH: Role of leptin in energy expenditure: The hypothalamic perspective. Am J Physiol Regul Integr Comp Physiol. 2017; 312(6): R938-R947.

PubMed Abstract | Publisher Full Text

17. McQueen AE, Koliwad SK, Wang J-C: Fighting obesity by targeting factors regulating beige adipocytes. Curr Opin Clin Nutr Metab Care. 2018; 21(6): 437-443.

PubMed Abstract | Publisher Full Text | Free Full Text

18. Zhu Q, Glazier BJ, Hinkel BC, et al.: Neuroendocrine Regulation of Energy Metabolism Involving Different Types of Adipose Tissues. Int J Mol Sci. 2019; 20(11): 2707.

PubMed Abstract | Publisher Full Text | Free Full Text

19. Park JS, Ha KH, He K, et al:: Association between Blood Mercury Level and Visceral Adiposity in Adults. Diabetes Metab J. 2017; 41(2): 113-20. PubMed Abstract | Publisher Full Text | Free Full Text

20. Camsari C, Folger JK, Rajput SK, et al:: Transgenerational Effects of Periconception Heavy Metal Administration on Adipose Weight and Glucose Homeostasis in Mice at Maturity. Toxicol Sci. 2019; 168(2): 610-9. PubMed Abstract | Publisher Full Text | Faculty Opinions Recommendation

21. Rizzetti DA, Corrales P, Piagette JT, et al:: Chronic mercury at low doses impairs white adipose tissue plasticity. Toxicology. 2019; 418: 41-50. PubMed Abstract | Publisher Full Text | Faculty Opinions Recommendation
22. Kawakami T, Hanao N, Nishiyama K, et al:: Differential effects of cobalt and mercury on lipid metabolism in the white adipose tissue of high-fat diet-induced obesity mice. Toxicol Appl Pharmacol. 2012; 258(1): 32-42.

PubMed Abstract | Publisher Full Text

23. Caito SW, Newell-Caito J, Martell M, et al:: Methylmercury Induces Metabolic Alterations in Caenorhabditis elegans: Role for C/EBP Transcription Factor. Toxicol Sci. 2020; 174(1): 112-123.

PubMed Abstract | Publisher Full Text | Free Full Text

24. Ferrer B, Peres TV, Dos Santos AA, et al.: Methylmercury Affects the Expression of Hypothalamic Neuropeptides That Control Body Weight in C57BL/6J Mice. Toxicol Sci. 2018; 163(2): 557-68.

PubMed Abstract | Publisher Full Text | Free Full Text

25. Mountjoy KG: Pro-Opiomelanocortin (POMC) Neurones, POMC-Derived Peptides, Melanocortin Receptors and Obesity: How Understanding of this System has Changed Over the Last Decade. J Neuroendocrinol. 2015; 27(6): 406-18.

PubMed Abstract | Publisher Full Text

26. Tinant $\mathrm{G}$, Neefs I, Rees J-F, et al.: Is methylmercury a new candidate obesogen? Proc Nutr Soc. 2020; 79.

Publisher Full Text

27. Jagannathan L, Jose CC, Tanwar VS, et al.: Identification of a unique gene expression signature in mercury and 2,3,7,8-tetrachlorodibenzo-p-dioxin coexposed cells. Toxicol Res (Camb). 2017; 6(3): 312-23. PubMed Abstract | Publisher Full Text | Free Full Text

28. Chauhan S, Dunlap K, Duffy LK: Effects of Methylmercury and Theaflavin Digallate on Adipokines in Mature 3T3-L1 Adipocytes. Int J Mol Sci. 2019; 20(11): 2755.

PubMed Abstract | Publisher Full Text | Free Full Text | Faculty Opinions Recommendation

29. Mazidi M, Rezaie P, Kengne AP, et al:: VEGF, the underlying factor for metabolic syndrome; fact or fiction? Diabetes Metab Syndr. 2017; 11 Suppl 1: S61-S64. PubMed Abstract | Publisher Full Text

30. Vertigan T, Dunlap K, Reynolds A, et al.: Effects of Methylmercury exposure in 3T3-L1 Adipocytes. AIMS Environ Sci. 2017; 4(1): 94-111. Publisher Full Text

31. Freire C, Vrhovnik P, Fiket Ž, et al.: Adipose tissue concentrations of arsenic, nickel, lead, tin, and titanium in adults from GraMo cohort in Southern Spain: An exploratory study. Sci Total Environ. 2020; 719: 137458 PubMed Abstract | Publisher Full Text

32. Beier EE, Holz JD, Sheu TJ, et al.: Elevated Lifetime Lead Exposure Impedes Osteoclast Activity and Produces an Increase in Bone Mass in Adolescent Mice. Toxicol Sci. 2016; 149(2): 277-88.

PubMed Abstract | Publisher Full Text | Free Full Text

33. Martini CN, Gabrielli M, Bonifacino G, et al.: Lead enhancement of 3T3-L1 fibroblasts differentiation to adipocytes involves ERK, C/EBP $\beta$ and PPAR $\gamma$ activation. Mol Cell Biochem. 2018; 437(1-2): 37-44.

PubMed Abstract | Publisher Full Text | Faculty Opinions Recommendation

34. Beier EE, Inzana JA, Sheu TJ, et al.: Effects of Combined Exposure to Lead and High-Fat Diet on Bone Quality in Juvenile Male Mice. Environ Health Perspect. 2015; 123(10): 935-43.

PubMed Abstract | Publisher Full Text | Free Full Text

35. Martini CN, Sosa FN, Fuchs J, et al.: Effect of lead on proliferation, oxidative stress and genotoxic damage of 3T3-L1 fibroblasts. Toxicol Res (Camb). 2020; 9(3): 158-63.

PubMed Abstract | Publisher Full Text | Free Full Text |

Faculty Opinions Recommendation

36. Meyer DN, Crofts EJ, Akemann C, et al:: Developmental exposure to $\mathrm{Pb}^{2+}$ induces transgenerational changes to zebrafish brain transcriptome. Chemosphere. 2020; 244: 125527.

PubMed Abstract | Publisher Full Text | Free Full Text |

Faculty Opinions Recommendation

37. Engin A: Diet-induced obesity and the mechanism of leptin resistance. $A d v$ Exp Med Biol. In: Obesity and Lipotoxicity, Springer, Cham, 2017; 960: 381-397. PubMed Abstract | Publisher Full Text

38. Ceja-Galicia ZA, Daniel A, Salazar AM, et al.: Effects of arsenic on adipocyte metabolism: Is arsenic an obesogen? Mol Cell Endocrinol. 2017; 452: 25-32. PubMed Abstract | Publisher Full Text

39. Castriota F, Zushin PJH, Sanchez SS, et al:: Chronic arsenic exposure impairs adaptive thermogenesis in male C57BL/6J mice. Am J Physiol Endocrinol Metab. 2020; 318(5): E667-E677. PubMed Abstract | Publisher Full Text | Free Full Text | Faculty Opinions Recommendation 
Adiposity During High-Fat Feeding. Obesity (Silver Spring). 2020; 28(5): 932-41. PubMed Abstract | Publisher Full Text | Free Full Text |

Faculty Opinions Recommendation

41. Shearer JJ, Neto MF, Umbaugh CS, et al.: In Vivo Exposure to Inorganic Arsenic Alters Differentiation-Specific Gene Expression of Adipose-Derived Mesenchymal Stem/Stromal Cells in C57BL/6J Mouse Model. Toxicol Sci. 2017 157(1): 172-82.

PubMed Abstract | Publisher Full Text | Free Full Text

42. Song X, Li Y, Liu J, et al:: Changes in Serum Adiponectin in Mice Chronically Exposed to Inorganic Arsenic in Drinking Water. Biol Trace Elem Res. 2017; 179(1): 140-7.

PubMed Abstract | Publisher Full Text

43. Ahangarpour A, Alboghobeish S, Oroojan AA, et al.: Effects of Combined Exposure to Chronic High-Fat Diet and Arsenic on Thyroid Function and Lipid Profile in Male Mouse. Biol Trace Elem Res. 2018; 182(1): 37-48. PubMed Abstract | Publisher Full Text | Faculty Opinions Recommendation

44. Katsiki N, Mantzoros C, Mikhailidis DP: Adiponectin, lipids and atherosclerosis. Curr Opin Lipidol. 2017; 28(4): 347-54 PubMed Abstract | Publisher Full Text

45. Yadav S, Anbalagan M, Shi Y, et al:: Arsenic inhibits the adipogenic differentiation of mesenchymal stem cells by down-regulating peroxisome proliferator-activated receptor gamma and CCAAT enhancer-binding proteins. Toxicol In Vitro. 2013; 27(1): 211-9.

PubMed Abstract | Publisher Full Text

46. Xue P, Hou Y, Zuo Z, et al:: Long isoforms of NRF1 negatively regulate adipogenesis via suppression of PPAR $y$ expression. Redox Biol. 2020; 30: 101414.

PubMed Abstract | Publisher Full Text | Free Full Text |

Faculty Opinions Recommendation

47. Hou $Y, X u e P$, Woods $C G$, et al:: Association between arsenic suppression of adipogenesis and induction of CHOP10 via the endoplasmic reticulum stress response. Environ Health Perspect. 2013; 121(2): 237-43. PubMed Abstract | Publisher Full Text | Free Full Text

48. Renu K, Madhyastha $\mathrm{H}$, Madhyastha $\mathrm{R}$, et al.: Role of arsenic exposure in adipose tissue dysfunction and its possible implication in diabetes pathophysiology. Toxicol Lett. 2018; 284: 86-95. PubMed Abstract | Publisher Full Text

49. Beezhold K, Klei LR, Barchowsky A: Regulation of cyclin D1 by arsenic and microRNA inhibits adipogenesis. Toxicol Lett. 2017; 265: 147-55. PubMed Abstract | Publisher Full Text | Free Full Tex

50. Bae J, Jang Y, Kim H, et al.: Arsenite exposure suppresses adipogenesis, mitochondrial biogenesis and thermogenesis via autophagy inhibition in brown adipose tissue. Sci Rep. 2019; 9(1): 14464. PubMed Abstract | Publisher Full Text | Free Full Text | Faculty Opinions Recommendation

51. Zuo Z, Liu Z, Gao T, et al.: Prolonged inorganic arsenic exposure via drinking water impairs brown adipose tissue function in mice. Sci Total Environ. 2019; 668: 310-7.

PubMed Abstract | Publisher Full Text | Faculty Opinions Recommendation

52. Egger AE, Grabmann G, Gollmann-Tepeköylü C, et al:: Chemical imaging and assessment of cadmium distribution in the human body. Metallomics. 2019; 11(12): 2010-9. PubMed Abstract | Publisher Full Text

53. Echeverría R, Vrhovnik $\mathrm{P}$, Salcedo-Bellido I, et al.: Levels and determinants of adipose tissue cadmium concentrations in an adult cohort from Southern
Spain. Sci Total Environ. 2019; 670: 1028-36.

PubMed Abstract | Publisher Full Text

54. Green AJ, Hoyo C, Mattingly CJ, et al:: Cadmium exposure increases the risk of juvenile obesity: A human and zebrafish comparative study. Int $J$ Obes (Lond). 2018; 42(7): 1285-95

PubMed Abstract | Publisher Full Text | Free Full Text

55. Ba Q, Li M, Chen P, et al:: Sex-Dependent Effects of Cadmium Exposure in Early Life on Gut Microbiota and Fat Accumulation in Mice. Environ Health Perspect 2017; 125(3): 437-46.

PubMed Abstract | Publisher Full Text | Free Full Text

56. Knani L, Bartolini D, Kechiche S, et al:: Melatonin prevents cadmium induced bone damage: First evidence on an improved osteogenic/adipogenic differentiation balance of mesenchymal stem cells as underlying mechanism. J Pineal Res. 2019; 67(3): e12597.

PubMed Abstract | Publisher Full Text | Faculty Opinions Recommendation

57. Moynihan M, Telléz-Rojo MM, Colacino J, et al:: Prenatal Cadmium Exposure Is Negatively Associated With Adiposity in Girls Not Boys During Adolescence. Front Public Health. 2019; 7: 61. PubMed Abstract | Publisher Full Text | Free Full Text

Faculty Opinions Recommendation

58. Prabhu R, Ribeiro M, Kajdacsy-Balla A: The Toxic Effect of Environmental Cadmium on Visceral Adipose Tissue. The FASEB Journal. 2020; 34(S1): 1. Publisher Full Text

59. Lee EJ, Moon JY, Yoo BS: Cadmium inhibits the differentiation of 3T3-L1 preadipocyte through the C/EBP $\alpha$ and PPAR $\gamma$ pathways. Drug Chem Toxicol. 2012; 35(2): 225-31.

PubMed Abstract | Publisher Full Text

60. Calabrese EJ: The Emergence of the Dose-Response Concept in Biology and Medicine. Int J Mol Sci. 2016; 17(12): 2034

PubMed Abstract | Publisher Full Text | Free Full Text

61. Bosy-Westphal A, Braun W, Albrecht $\mathrm{V}$, et al.: Determinants of ectopic liver fat in metabolic disease. Eur J Clin Nutr. 2019; 73(2): 209-14. PubMed Abstract | Publisher Full Text

62. Zhai $\mathrm{H}$, Chen $\mathrm{C}$, Wang $\mathrm{N}$, et al:: Blood lead level is associated with nonalcoholic fatty liver disease in the Yangtze River Delta region of China in the context of rapid urbanization. Environ Health. 2017; 16(1): 93.

PubMed Abstract | Publisher Full Text | Free Full Text

63. Chen $\mathrm{R}, \mathrm{Xu} \mathrm{Y}, \mathrm{Xu} \mathrm{C}$, et al.: Associations between mercury exposure and the risk of nonalcoholic fatty liver disease (NAFLD) in US adolescents. Environ Sci Pollut Res Int. 2019; 26(30): 31384-91.

PubMed Abstract | Publisher Full Text

64. Frediani JK, Naioti EA, Vos MB, et al.: Arsenic exposure and risk of nonalcoholic fatty liver disease (NAFLD) among U.S. adolescents and adults: An association modified by race/ethnicity, NHANES 2005-2014. Environ Health. 2018; 17(1): 6

PubMed Abstract | Publisher Full Text | Free Full Text

65. Chen $\mathrm{P}$, Bornhorst $\mathrm{J}$, Neely MD, et al.: Mechanisms and Disease Pathogenesis Underlying Metal-Induced Oxidative Stress. Oxid Med Cell Longev. 2018; 2018: 7612172

PubMed Abstract | Publisher Full Text | Free Full Text

66. Bondy SC: Metal toxicity, inflammation and oxidative stress. In: Inflammation, Aging, and Oxidative Stress. Springer, Cham. 2016; 3-16. Publisher Full Text

67. Planchart A, Green A, Hoyo C, et al:: Heavy Metal Exposure and Metabolic Syndrome: Evidence from Human and Model System Studies. Curr Environ Health Rep. 2018; 5(1): 110-24.

PubMed Abstract | Publisher Full Text | Free Full Text 